\title{
Iron isotopic evidence for convective resurfacing of recycled arc-front mantle beneath back-arc basins
}

\author{
O. Nebel, ${ }^{1}$ R. J. Arculus, ${ }^{1}$ P. A. Sossi, ${ }^{1}$ F. E. Jenner, ${ }^{2}$ and T. H. E. Whan ${ }^{1}$ \\ Received 12 September 2013; revised 22 October 2013; accepted 28 October 2013; published 26 November 2013.
}

[1] Geophysical observations suggest sub-arc convective flow transports melt-exhausted and metasomatized wedge mantle into deeper mantle regions. Reciprocally, asthenospheric, fertile mantle may supply back-arc ridges distal to the trench by shallow, lateral mantle ingress, insinuating initial wedge mantle depletion in its back-arc region. Here we show that light Fe isotope compositions of the Central Lau Spreading Centre located in the Lau back-arc basin on the farside of the Tonga-Kermadec arc are indicative for derivation from a modified arc-front mantle with elemental and $\mathrm{Nd}$-isotopic memory of former slab fluid addition. We propose that this shallow wedge material has been transported from the sub-arc mantle to the back-arc either convectively or in a buoyant diapir. This implies that melt-depleted mantle in subduction zones is, at least in parts, recycled in a resurfacing loop. This can explain the depletion in back-arc regions, and the progressively depleted nature of island arc sources in maturing arc systems. Citation: Nebel, O., R. J. Arculus, P. A. Sossi, F. E. Jenner, and T. H. E. Whan (2013), Iron isotopic evidence for convective resurfacing of recycled arc-front mantle beneath back-arc basins, Geophys. Res. Lett., 40, 5849-5853, doi:10.1002/2013GL057976.

\section{Introduction}

[2] It is well established that volatile components leave the subducting slab under elevated pressures and temperatures at convergent oceanic plate margins, triggering metasomatism and subsequent flux melting in the mantle wedge overlying the slab. Arc-derived melts are thus enriched in volatiles and so-called fluid-mobile elements [Pearce and Peate, 1995], leaving behind a super depleted and partially metasomatized wedge mantle. It is long known that most arc melts are sourced from a wedge with a multiple depletion history [Woodhead et al., 1993]. Loci and time scales of prior melting events remain enigmatic but are commonly attributed to preconditioning by melting at back-arcs and subsequent mantle advection [Hall et al., 2012; Kincaid and Hall, 2003; McCulloch and Gamble, 1991]. Depending on slab geometry,

Additional supporting information may be found in the online version of this article.

${ }^{1}$ Research School of Earth Sciences, The Australian National University, Canberra, Australian Capital Territory, Australia.

${ }^{2}$ Department of Environment, Earth and Ecosystems, The Open University, Milton Keynes, UK.

Corresponding author: O. Nebel, Research School of Earth Sciences, The Australian National University, Mills Road, Building 61, Acton, Canberra, ACT 0200, Australia. (oliver.nebel@anu.edu.au)

(C)2013. American Geophysical Union. All Rights Reserved. 0094-8276/13/10.1002/2013GL057976 subduction speed and local temperature gradients, dehydration of the slab occurs at 100 to up to $400 \mathrm{~km}$ surface distance from the trench [van Keken et al., 2011], as evidenced by the distribution of arc magmas. Signatures of such a process are virtually absent in distal back-arc basin basalts (BABB) [Langmuir et al., 2006; Tian et al., 2008]. The apparent absence of a fluid-dependent arc signature in BABB suggests either (i) stagnation/stabilization of progressively depleted wedge material beneath maturing sub-arcs or (ii) dragging of wedge material into the deeper mantle, followed by possible admixture with the convecting asthenospheric mantle. The ultimate fate of sub-arc mantle is governed by the ambient mantle flow regime, which is dependent, to a large degree, on the kinematics of the subducting slab. Depending on slab temperature, velocity, and age, near-arc mantle motion occurs as a complex interplay of trench parallel flow, poloidal wedge convection, and maybe deeper mantle upwelling [Harmon and Blackman, 2010; Smith et al., 2001; Turner and Hawkesworth, 1998; Zhang and Pysklywec, 2006]. In contrast, mantle flow underneath oceanic ridges is passive, in that it is dictated by the broader asthenospheric mantle flow regime and overriding plate motions. Therefore, back-arc ridges are ideally suited for geochemical mapping of the regional mantle flow regime. However, geochemical data in the far back-arc region have so far failed to provide compelling evidence for the presence of fertile asthenospheric mantle or arc wedge material in their source, and with this its return to the melting column through mantle upwelling.

[3] The Lau Basin comprises part of the Lau-Fiji BAB, the largest and fastest-spreading present-day back-arc system. Its "V-shaped" basin morphology hosts a series of spreading centers and transforms faults including the Central Lau Spreading Centre (CLSC). The Tonga-Kermadec subduction zone at its eastern flank and the paleo-Vitiaz subduction zone to its north (Fig. Fs01a, supporting information) have modified the chemistry of the local mantle by metasomatism through the influx of subduction components and the subsequent depletion of fertile components by melt extraction [Bezos et al., 2009; Escrig et al., 2012; Keller et al., 2008; Langmuir et al., 2006; Pearce et al., 2007; Taylor and Martinez, 2003; Tian et al., 2008; Turner and Hawkesworth, 1998]. Basaltic sea floor samples dredged throughout the Basin show that the subduction-modified mantle, defined by elevated large-ion lithophile elements and volatiles, is largely confined to a surface distance to the active Tonga-Kermadec trench of approximately $200 \mathrm{~km}$ (Figure 1a) [Martinez and Taylor, 2002].

[4] The CLSC samples local mantle with a typical depleted mantle character, lacking evidence for active subduction influence in major and trace elements and radiogenic isotopes [Tian et al., 2008]. Source fertility and subduction-modified mantle can be traced in $\mathrm{Th}-\mathrm{Yb}-\mathrm{Nb}$ systematics for similar pressure-temperature regimes and degrees of melting [Pearce and 

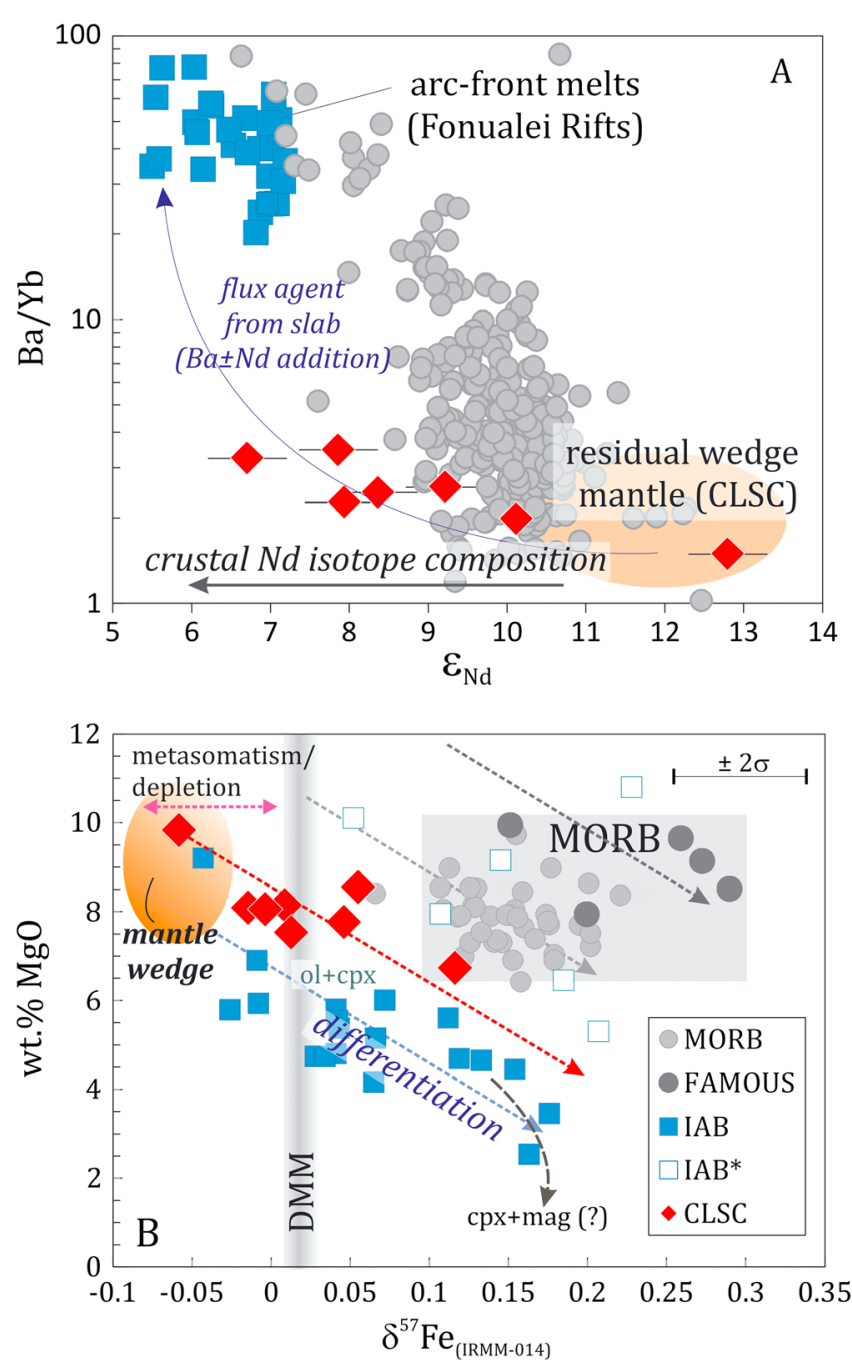

Figure 1. Geochemical memory of wedge mantle melting in BAB rocks. (a) Negative covariation of CLSC rocks reflects modification by prior slab fluid addition in the wedge area indicated by the coupled fluid mobility of $\mathrm{Ba}$ and light rare earth elements $(\mathrm{Nd})$. Samples from the Fonualei rifts [Escrig et al., 2012] contain a flux agent, whereas CLSC samples are derived from residual mantle sections and only carry a memory of this agent. Pacific MORB samples are shown for comparison (www.georoc.com). (b) Island arc basalt (IAB, Bismarck arc, Mariana arc, Izu Bonin arc) [Dauphas et al., 2009] and CLSC sources (with primitive $\mathrm{MgO}$ ) are isotopically lighter as compared to MORB, reflecting mantle wedge depletion. Dotted arrows indicate fractionation patterns of olivine and pyroxene $(\mathrm{Ol}+\mathrm{Prx})$ indicating that most primitive MORB melts contain $\sim 11 \mathrm{wt}$. $\mathrm{MgO}$ (depending on fractionation during melting); some FAMOUS samples have parental liquids with higher $\mathrm{MgO}$ [Gale et al., 2013]. Arc rocks with open symbols (IAB*) presumably share a more fertile source or have more oxidized sources; $\mathrm{DMM}=$ depleted MORB mantle [Craddock et al., 2013]; MORB sources are Beard et al. [2003], Teng et al. [2013], and Weyer and Ionov [2007].

Peate, 1995]. The CLSC plots in the range of open ocean ridges (Fig. Fs01b, supporting information), yet on their depleted end. Active slab component addition indicated by elevated Th is apparent for rocks that are overprinted by a flux agent from the subducted slab, as e.g., the Fonualei Rifts (Fig. Fs01b, supporting information) [Escrig et al., 2012], whereas CLSC samples are derived from a more depleted source. Even though the CLSC is lacking active slab fluid overprinting, memory of subduction imprint is indicated by subtle covariations in crustally derived $\mathrm{Nd}$ isotope signals with fluid-mobile $\mathrm{Ba}$ (Figure 1a) - very unlike ordinary MORB mantle. Notably, no such variation is observed with $\mathrm{Hf}$ isotopes, emphasizing memory of metasomatism by the enhanced fluid mobility of $\mathrm{Nd}>\mathrm{Hf}$ in slab-derived fluids. Support for compositionally different mantle is further provided by seismic tomography for the deeper Lau BAB showing low-velocity zones exceeding $400 \mathrm{~km}$ in depth underneath the CLSC [Zhao et al., 1997]. Intermediate variation in seismic tomography of $1-3 \%$ slower $P$ wave velocity as compared to the melting regime underneath the ridge (with $\sim 6 \%$ lower wave velocity) [Zhao et al., 1997] calls for a cause other than melting at the spreading ridge. The slow $P$ wave velocities suggest either hotter mantle or compositional variations in the deeper Lau Basin mantle; the latter either related to prior melt extraction or fluid infiltration. It can be argued that shape, spatial distribution, and depth of this anomalous mantle relate to melt production/metasomatism in the subduction zone underlying the active arc front [Zhao et al., 1997], implying that subduction-modified mantle is dragged down by the subducting slab, in favor of deep-mantle recycling of wedge mantle. A series of attempts, including modeling of mantle flow [Harmon and Blackman, 2010] and geochemical tracing [Pearce et al., 2007; Taylor and Martinez, 2003; Tian et al., 2008], has been unsuccessful in clearly identifying depleted wedge material and/or definite slab components at the CLSC, meaning that evidence for a link between wedge recycling and deep Lau seismic velocity anomalies remains elusive.

[5] Here we use stable Fe isotopes in conjunction with the classical radiogenic Hf-Nd isotopes, as probes for investigating the fertility and origin of the mantle source in back-arc regions and to test if arc-modified mantle gets transported into the deeper mantle or is upwelling at $\mathrm{BAB}$ ridges.

\section{Iron Isotope Evidence for a Depleted Wedge Source}

[6] Redox-controlled $\mathrm{Fe}$ isotope fractionation gives rise to resolvable variations in mantle rocks and minerals [Teng et al., 2008; Weyer et al., 2007; Williams et al., 2005]. The ${ }^{57} \mathrm{Fe} /{ }^{54} \mathrm{Fe}$ (expressed as $\delta^{57} \mathrm{Fe}$ relative to the IRMM-014 std. solution; see analytical section for definition) fractionate during mantle melting as a function of $\mathrm{Fe}$ oxidation state [Williams et al., 2005; Williams et al., 2009], i.e., ferric $\left(\mathrm{Fe}^{3+}\right)$-ferrous $\left(\mathrm{Fe}^{2+}\right)$ ratio (expressed as $\mathrm{Fe}^{3+} / \Sigma \mathrm{Fe}$ ), which sets the oxygen fugacity (expressed as $f_{2}$, relative to the synthetic fayalite-magnetite-quartz buffer $\mathrm{FMQ}=0$ ). $\mathrm{As} \mathrm{Fe}^{3+}$ is more incompatible during mantle melting than is $\mathrm{Fe}^{2+}$, heavy iron isotopes are preferentially enriched in melts with respect to their source. Correspondingly, the residual becomes progressively lighter as the heavy iron escapes into the melt, such that the most depleted peridotites are also the most reduced and have the lightest iron isotope compositions (supporting information). A second parameter that can alter the Fe isotope composition of the mantle is metasomatism 


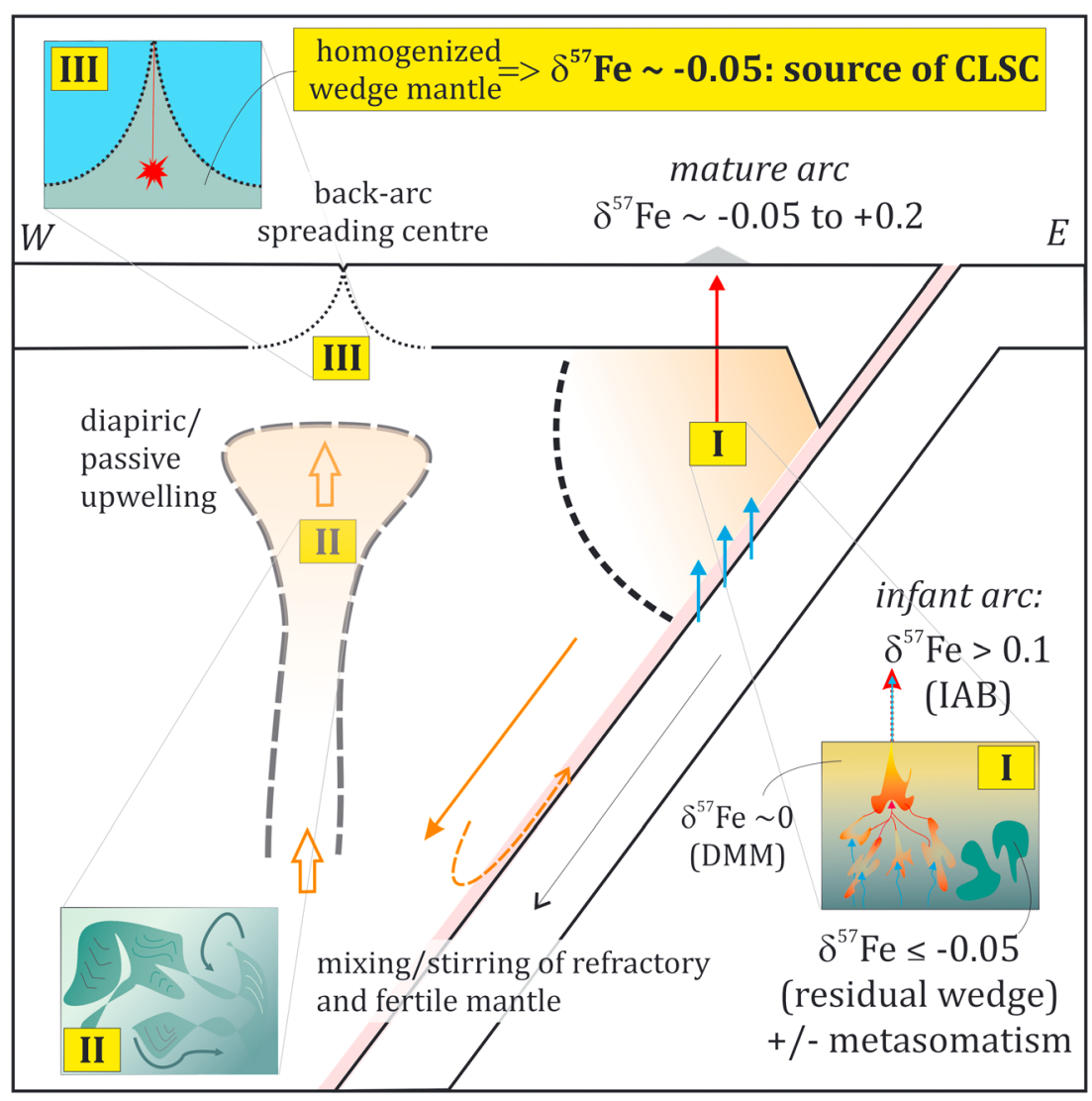

Figure 2. Three-stage model for Fe isotope evolution in back-arcs. Schematic sketch of processes that lead to the fractionation of $\mathrm{Fe}$ isotopes in island arc settings and the recycling of diapiring wedge mantle. I is the area of melting/metasomatism underneath the arc front in the mantle wedge. Infant arcs are assumed to have fertile Fe isotope mantle compositions with $\delta^{57} \mathrm{Fe} \sim 0$ [Weyer and Ionov, 2007]; metasomatized/refractory wedge has a $\delta^{57} \mathrm{Fe} \sim-0.1$ [Dauphas et al., 2009]; II is the area of homogenization in the diapiring mantle under the spreading ridge; refractory and fertile sections merge and form an average $\delta^{57} \mathrm{Fe} \sim-0.05$; III is the area of melting underneath back-arc ridges with $\delta^{57} \mathrm{Fe}=-0.05$.

[Poitrasson et al., 2013; Zhao et al., 2010]. Irrespective of the metasomatic agent, refertilization by metasomatism results in a lighter Fe isotope composition as compared to the pristine mantle with effects exceeding those of melt depletion [Poitrasson et al., 2013].

[7] Irrespective of source variability in $\mathrm{Fe}$ isotopes, in mafic igneous systems, crystal fractionation of olivine \pm pyroxene causes a decrease in $\mathrm{MgO}$ that is accompanied with a progressive increase in $\delta^{57} \mathrm{Fe}$, presumably by the removal of $\mathrm{Fe}^{2+}$ [Teng et al., 2008]. In oceanic mantle, isotope fractionation upon melting of depleted mid-ocean ridge basalt (MORB) mantle (DMM with an average of $\delta^{57} \mathrm{Fe} \sim 0$ ) [Craddock et al., 2013], though with considerable spread as to metasomatism [Poitrasson et al., 2013; Zhao et al., 2010] results in the formation of primitive MORB with approximately $10 \mathrm{wt} \% \mathrm{MgO}$ [Jenner and O'Neill, 2012] and a $\delta^{57} \mathrm{Fe}>+0.1 \%$ [Teng et al., 2013] for typical degrees of melting between 15 and 20\% [Weyer and Ionov, 2007]. In contrast, global island arc basalts (IAB) come from a mantle wedge source that is, on average, more depleted than DMM [Pearce and Peate, 1995; Woodhead et al., 1993] and have indeed been demonstrated to be isotopically lighter in Fe [Dauphas et al., 2009]. In all cases, it is important to identify the primary magma composition, as iron isotopes in terrestrial magmatic rocks appear to be modified in a predictable manner by crystal fractionation [Poitrasson and Freydier, 2005; Sossi et al., 2012]. While arc basalts are unequivocally more oxidized than MORB [Parkinson and Arculus, 1999], conjecture abounds as to whether they attain this oxidized character from their source or during their ascent. Ferric iron contents of spinels in arc peridotites indicate a source that is more oxidized $(\approx \mathrm{FMQ}=+0.5$ to $\mathrm{FMQ}=+2)$ than their shallow oceanic counterparts $(\mathrm{FMQ}=0$ to $\mathrm{FMQ}=-1)$ [Parkinson and Arculus, 1999]. Hence, the difference between MORB and IAB mantle sources may be elucidated by iron isotopes, which can track melt extraction and/or metasomatism. The decrease towards lighter $\delta^{57} \mathrm{Fe}$ in more refractory peridotites, as found in the mantle wedge, offers a tool to trace mantle wedge signatures in BAB. Indeed, Dauphas and coworkers [Dauphas et al., 2009] showed covariations of $\delta^{57} \mathrm{Fe}$ with Ti contents for the active Bismarck and Izu Bonin arcs (Figure 1b) with an initial arc sources of $\delta^{57} \mathrm{Fe}<0$, in agreement with residual mantle sections that exhibit $\delta^{57} \mathrm{Fe} \sim-0.05$ to -0.10 after $\sim 15-20 \%$ melt depletion [Weyer and Ionov, 2007].

[8] Samples from the CLSC have $\delta^{57} \mathrm{Fe} \sim 0$ considerably lighter than ocean ridge lavas, which have $\delta^{57} \mathrm{Fe}>+0.1$ (Figure 1b) [Teng et al., 2013]. Projection back to the primitive melt composition for the CLSC at $\sim 10 \mathrm{wt} \% \mathrm{MgO}$ yields $\delta^{57} \mathrm{Fe}=-0.05$ to $-0.10 \%$ (Figure $1 \mathrm{~b}$, which is 
considerably lighter than fertile upper mantle (DMM is $\left.\delta^{57} \mathrm{Fe} \sim 0\right)$ ) [Craddock et al., 2013]. Figure 1b shows that the CLSC samples are systematically lighter in Fe isotopes for a given $\mathrm{MgO}$ than global MOR lavas and approach those of primitive IAB [Dauphas et al., 2009] and their projected mantle wedge sources. In a similar manner, $\mathrm{Fe}$ isotopes of enriched French-American Mid-Ocean Undersea Study (FAMOUS) samples, often referred to as E-MORB, plot on the heavy end of MORB Fe isotopes for a given $\mathrm{MgO}$ content. This requires a primary melt with higher $\mathrm{MgO}$ content compared to N-MORB, so they experienced more fractionation to achieve heavy $\delta^{57} \mathrm{Fe}$ for $\mathrm{MgO}$ between 8 and 10 wt.\%. Indeed, that appears to be the case [Gale et al., 2013], identifying crystal fractionation as a key process in fractionating Fe isotopes in evolving melts. This is important so that $\mathrm{MgO}$ acts as a proxy for differentiation for Fe isotopes until magnetite saturation is achieved [Sossi et al., 2012]. Hence, trajectories in Figure 1b relate to effects of crystal fractionation of pyroxene and olivine, the major $\mathrm{Mg}$-Fe-bearing phases during crystal fractionation. Conclusively, seemingly similar Fe isotope values in IAB and MORB are not reflecting a similar mantle source isotope composition.

[9] The cause for their light $\mathrm{Fe}$ isotope compositions in the CLSC samples compared to MORB is best explained by a melt-depleted and metasomatized source similar to those observed in IAB. This source is the sub-arc mantle wedge that experienced a prior loss of $\mathrm{Fe}^{3+}$ by melt extraction and injection of $\mathrm{Fe}^{2+}$ by metasomatic fluids, which in turn caused a decrease in $f_{2}$ in mantle sourcing the CLSC as compared to MORB samples. We suspect that the combined effect of melt depletion, subsequent metasomatism, and/or admixture of fertile mantle sections will cause scatter in Fe isotope composition of the CLSC mantle source, resulting in parallel arrays in $\mathrm{MgO}$ versus $\delta^{57} \mathrm{Fe}$, as indicated in figure $1 \mathrm{~b}$. Based on the similarity with IAB sources in $\delta^{57} \mathrm{Fe}$ and slab fluid memory in Ba-Nd systematics (Figure 1a), we propose that at least parts of the highly depleted local mantle sourcing the CLSC is derived from regions that previously resided underneath the arc front.

\section{Modes and Depths of Mantle Upwelling in BAB}

[10] The presence of refractory/metasomatized mantle wedge material sourcing the CLSC distal to the arc front requires convective mobility of melt-exhausted wedge material. We propose a mechanism whereby proximal arc-front mantle is dragged down to depth underneath the Basin coupled with the subducting slab, maybe assisted by wedge convection. Super depleted sections are compositionally buoyant and support a resurfacing of these sections in an instable diapiric flow [Hall and Kincaid, 2001]. A vertical motion of such buoyant depleted mantle sections can be assisted by seafloor spreading with passive upwelling of supplying mantle underneath the ridge (Figure 2). Notably, such ultradepleted diapirs can occur beyond the influence of slab dehydration with relatively cold or hot matrices [Gerya and Yuen, 2003]. To explain our geochemical observations, we suggest that during the deep-mantle cycle, mixing and homogenization of metasomatized, upwelling arc-mantle with fertile ambient mantle resulted in a $\mathrm{Fe}$ isotope signature for the CLSC between MORB and IAB sources (Figure 2). Metasomatized source mantle beneath the CLSC would occur as discrete volumes embedded within the ambient mantle with a characteristic spacing given by the along-strike wavelength of the buoyant instabilities [Marsh, 1979] and thus constitute only a small fraction of the sub-back-arc spreading center mantle by volume. In this scenario, subtle variations of fluid-mobile elements, such as Nd-Ba (Figure 1), $\mathrm{Sr}, \mathrm{Pb}$ [Tian et al., 2008], and in particular $\mathrm{Fe}^{2+}$ (memorized in Fe isotopes) in CLSC samples bear witness to prior metasomatism by flux melting underneath the arc front. Because refractory mantle is difficult to melt, metasomatism is proposed here as the main process of $\mathrm{Fe}$ isotope alteration, explaining the dominance in $\mathrm{Fe}$ isotopes of the arc-modified mantle signatures in CLSC samples.

[11] The resurfacing of depleted/metasomatized wedge material in the Lau Basin implies that wedge mantle recycling is an effective process to preserve depleted mantle sections by rotation in a recycling loop. In addition to depletion by backarc melting and convective transportation toward the arc front [Hall et al., 2012], this may explain why some IAB sources are depleted in incompatible elements by multiple phase melt extraction, as e.g., in high-field strength elements (HFSE), compared to their MORB counterparts, [Pearce and Peate, 1995; Woodhead et al., 1993]. Even though some arc sources may retain their fertility [Thirlwall et al., 1994], likely depending on rehomogenization during wedge convection or age of the subduction zone, the depletion in HFSE in most arc sources may thus relate to prolonged melt extraction in a maturing and partially recycled local mantle.

[12] If depleted/metasomatized sections are indeed identified by seismic velocity anomalies underneath the Lau Basin, then wedge-modified mantle occurs as deep as $400 \mathrm{~km}$ underneath the CLSC and down to the $660 \mathrm{~km}$ discontinuity further to the west [Zhao et al., 1997], suggesting that hot asthenospheric mantle from $>400 \mathrm{~km}$ depths can be either sourced or at least affected in its mobility by spreading at the overlying ridge. Indeed, a deeper, asthenospheric origin of shallow mantle in the northern Lau BAB is further supported by a positive thermal mantle anomaly in the North Fiji and Lau Basins [Lagabrielle et al., 1997; Zhang and Pysklywec, 2006]. Hence, we propose that the CLSC and maybe other oceanic ridges are at least influenced by but may actively mobilize mantle from regions far deeper than their respective melt regimes at $<100 \mathrm{~km}$ depth by poloidal advection, possibly as deep as the mantle transition zone.

[13] Reciprocally, deeper mantle regions below the mantle transition zone may be more isolated from near-surface melt depletion events. The upper mantle is considered geochemically depleted in crustal components but exhibits a constant $\mathrm{Fe}$ isotope composition [Craddock et al., 2013], so it seems that the $\mathrm{Fe}$ isotope composition of the upper mantle is controlled by fertile mantle sections that are clearly not metasomatized. Accordingly, with geologic time, remixing of refractory/metasomatized wedge mantle sections into the convecting fertile mantle must have been an efficient process, at least to extents that are resolvable in Fe isotope analyses. Whereas Fe isotope anomalies in the mantle that formed in subduction zones may be erased by convective homogenization, systematically lighter Fe isotope compositions in preserved mantle-derived melts can be used as tracers for ancient ultradepleted mantle sections that are related to subduction activity. This qualifies Fe isotopes as a possible tool in search for global mantle heterogeneity, to track mantle flow or may assist in search for modern-style subduction signatures in the ancient rock record. 
[14] Acknowledgments. This work was funded by the Australian Research Council, DE120100513 and DP120104240. We thank the crew of the research vessel RV Southern Surveyor and the Australian Marine National Facility for their support. Graham Mortimer is kindly acknowledged for his laboratory assistance, and we are grateful for comments by F. Poitrasson and S. Escrig that helped to improve the manuscript. Suggestions by two anonymous journal reviewers greatly improved the clarity of our model.

[15] The Editor thanks two anonymous reviewers for their assistance in evaluating this paper.

\section{References}

Beard, B. L., C. M. Johnson, J. L. Skulan, K. H. Nealson, L. Cox, and H. Sun (2003), Application of $\mathrm{Fe}$ isotopes to tracing the geochemical and biological cycling of Fe, Chem. Geol., 195(1-4), 87-117, doi:10.1016/s0009-2541(02) 00390-x.

Bezos, A., S. Escrig, C. H. Langmuir, P. J. Michael, and P. D. Asimow (2009), Origins of chemical diversity of back-arc basin basalts: A segmentscale study of the Eastern Lau Spreading Center, J. Geophys. Res. 114, B06212, doi:10.1029/2008JB005924.

Craddock, P. R., J. M. Warren, and N. Dauphas (2013), Abyssal peridotites reveal the near-chondritic Fe isotopic composition of the Earth, Earth Planet. Sci. Lett., 365, 63-76, doi:10.1016/j.eps1.2013.01.011.

Dauphas, N., P. R. Craddock, P. D. Asimow, V. C. Bennett, A. P. Nutman, and D. Ohnenstetter (2009), Iron isotopes may reveal the redox conditions of mantle melting from Archean to present, Earth Planet. Sci. Lett., 288(1-2), 255-267, doi:10.1016/j.epsl.2009.09.029.

Escrig, S., A. Bézos, C. H. Langmuir, P. J. Michael, and R. J. Arculus (2012), Characterizing the effect of mantle source, subduction input and melting in the Fonualei Spreading Center, Lau Basin: Constraints on the origin of the boninitic signature of the back-arc lavas, Geochem. Geophys. Geosyst., 13, Q10008, doi:10.1029/2012GC004130.

Gale, A., M. Laubier, S. Escrig, and C. H. Langmuir (2013), Constraints on melting processes and plume-ridge interaction from comprehensive study of the FAMOUS and North Famous segments, Mid-Atlantic Ridge, Earth Planet. Sci. Lett., 365, 209-220, doi:10.1016/j.eps1.2013.01.022.

Gerya, T. V., and D. A. Yuen (2003), Rayleigh-Taylor instabilities from hydration and melting propel "cold plumes" at subduction zones, Earth Planet. Sci. Lett., 212(1-2), 47-62, doi:10.1016/s0012-821x(03)00265-6.

Hall, P. S., and C. Kincaid (2001), Diapiric flow at subduction zones: A recipe for rapid transport, Science, 292(5526), 2472-2475, doi:10.1126 science. 1060488 .

Hall, P. S., L. B. Cooper, and T. Plank (2012), Thermochemical evolution of the sub-arc mantle due to back-arc spreading, J. Geophys. Res., 117, B02201, doi:10.1029/2011JB008507.

Harmon, N., and D. K. Blackman (2010), Effects of plate boundary geometry and kinematics on mantle melting beneath the back-arc spreading centers along the Lau Basin, Earth Planet. Sci. Lett., 298(3-4), 334-346, doi:10.1016/j.epsl.2010.08.004.

Jenner, F. E., and H. S. C. O'Neill (2012), Analysis of 60 elements in 616 ocean floor basaltic glasses, Geochem. Geophys. Geosyst., 13, Q02005, doi:10.1029/2011GC004009.

Keller, N. S., R. J. Arculus, J. Hermann, and S. Richards (2008), Submarine back-arc lava with arc signature: Fonualei Spreading Center, northeast Lau Basin, Tonga, J. Geophys. Res., 113, B08S07, doi:10.1029/2007JB005451.

Kincaid, C., and P. S. Hall (2003), Role of back arc spreading in circulation and melting at subduction zones, J. Geophys. Res., 108(B5), 2240, doi:10.1029/2001JB001174.

Lagabrielle, Y., J. Goslin, H. Martin, J. L. Thirot, and J. M. Auzende (1997) Multiple active spreading centres in the hot north Fiji basin (southwest Pacific): A possible model for Archaean seafloor dynamics?, Earth Planet. Sci. Lett., 149(1-4), 1-13, doi:10.1016/s0012-821x(97)00060-5.

Langmuir, C. H., A. Bezos, S. Escrig, and S. W. Parman (2006), Chemical systematics and hydrous melting of the mantle in back-arc, basins, in Back-Arc Spreading Systems: Geological, Biological, Chemical, and Physical Interactions, edited by D. M. Christie et al., pp. 87-146, AGU, Washington, D. C., doi:10.1029/166GM07.

Marsh, B. D. (1979), Island arc development-Some observations, experiments and speculations, J. Geol., 87(6), 687-713, doi:10.1086/628460.

Martinez, F., and B. Taylor (2002), Mantle wedge control on back-arc crustal accretion, Nature, 416(6879), 417-420, doi:10.1038/416417a.

McCulloch, M. T., and J. A. Gamble (1991), Geochemical and geodynamic constraints on subduction zone magmatism, Earth Planet. Sci. Lett., 102(3-4), 358-374, doi:10.1016/0012-821x(91)90029-h.

Parkinson, I. J., and R. J. Arculus (1999), The redox state of subduction zones: Insights from arc-peridotites, Chem. Geol., 160(4), 409-423, doi:10.1016/S0009-2541(99)00110-2.

Pearce, J. A., and D. W. Peate (1995), Tectonic implications of the composition of volcanic arc magmas, Annu. Rev. Earth Planet. Sci., 23, 251-285, doi:10.1146/annurev.ea.23.050195.001343.
Pearce, J. A., P. D. Kempton, and J. B. Gill (2007), Hf-Nd evidence for the origin and distribution of mantle domains in the SW Pacific, Earth Planet. Sci. Lett., 260(1-2), 98-114, doi:10.1016/i.epsl.2007.05.023.

Poitrasson, F., and R. Freydier (2005), Heavy iron isotope composition of granites determined by high resolution MC-ICP-MS, Chem. Geol., 222(1-2), 132-147, doi:10.1016/j.chemgeo.2005.07.005.

Poitrasson, F., G. Delpech, and M. Grégoire (2013), On the iron isotope heterogeneity of lithospheric mantle xenoliths: Implications for mantle metasomatism, the origin of basalts and the iron isotope composition of the Earth, Contrib. Mineral. Petrol., 165(6), 1243-1258, doi:10.1007/ s00410-013-0856-7.

Smith, G. P., D. A. Wiens, K. M. Fischer, L. M. Dorman, S. C. Webb, and J. A. Hildebrand (2001), A complex pattern of mantle flow in the Lau backarc, Science, 292(5517), 713-716, doi:10.1126/science.1058763.

Sossi, P. A., J. D. Foden, and G. P. Halverson (2012), Redox-controlled iron isotope fractionation during magmatic differentiation: An example from the Red Hill intrusion, S. Tasmania, Contrib. Mineral. Petrol., 165(5), 757-772, doi:10.1007/s00410-012-0769-x.

Taylor, B., and F. Martinez (2003), Back-arc basin basalt systematics, Earth Planet. Sci. Lett., 210(3-4), 481-497, doi:10.1016/s0012-821x (03)00167-5.

Teng, F. Z., N. Dauphas, and R. T. Helz (2008), Iron isotope fractionation during magmatic differentiation in Kilauea Iki Lava Lake, Science, 320(5883), 1620-1622, doi:10.1126/science.1157166.

Teng, F. Z., N. Dauphas, S. Huang, and B. Marty (2013), Iron isotopic systematics in oceanic basalts, Geochim. Cosmochim. Acta, 107, 12-26, doi:10.1016/j.gca.2012.12.027.

Thirlwall, M. F., T. E. Smith, A. M. Graham, N. Theodorou, P. Hollings, J. P. Davidson, and R. J. Arculus (1994), High-field strength element anomalies in arc lavas-Source or process, J. Petrol., 35(3), 819-838, doi:10.1093/petrology/35.3.819.

Tian, L., P. R. Castillo, J. W. Hawkins, D. R. Hilton, B. B. Hannan, and A. J. Pietruszka (2008), Major and trace element and Sr-Nd isotope signatures of lavas from the Central Lau Basin: Implications for the nature and influence of subduction components in the back-arc mantle, J. Volcanol. Geotherm. Res., 178(4), 657-670, doi:10.1016/j.jvolgeores.2008.06.039.

Turner, S., and C. Hawkesworth (1998), Using geochemistry to map mantle flow beneath the Lau Basin, Geology, 26(11), 1019-1022, doi:10.1130/ 0091-7613.

van Keken, P. E., B. R. Hacker, E. M. Syracuse, and G. A. Abers (2011), Subduction factory: 4. Depth-dependent flux of $\mathrm{H}_{2} \mathrm{O}$ from subducting slabs worldwide, J. Geophys. Res., 116, B01401, doi:10.1029/ $2010 \mathrm{JB} 007922$.

Weyer, S., and D. A. Ionov (2007), Partial melting and melt percolation in the mantle: The message from $\mathrm{Fe}$ isotopes, Earth Planet. Sci. Lett., 259(1-2), 119-133, doi:10.1016/j.eps1.2007.04.033.

Weyer, S., A. D. Anbar, G. P. Brey, C. Munker, K. Mezger, and A. B. Woodland (2007), Fe-isotope fractionation during partial melting on Earth and the current view on the Fe-isotope budgets of the planets (reply to the comment of F. Poitrasson and to the comment of B.L. Beard and C.M. Johnson on "Iron isotope fractionation during planetary differentiation" by S. Weyer, A.D. Anbar, G.P. Brey, C. Munker, K. Mezger and A.B. Woodland), Earth Planet. Sci. Lett., 256(3-4), 638-646, doi:10.1016/j. eps1.2007.01.038.

Williams, H. M., A. H. Peslier, C. McCammon, A. N. Halliday, S. Levasseur, N. Teutsch, and J. P. Burg (2005), Systematic iron isotope variations in mantle rocks and minerals: The effects of partial melting and oxygen fugacity, Earth Planet. Sci. Lett., 235(1-2), 435-452, doi:10.1016/j. epsl.2005.04.020.

Williams, H. M., S. G. Nielsen, C. Renac, W. L. Griffin, S. Y. O'Reilly, C. A. McCammon, N. Pearson, F. Viljoen, J. C. Alt, and A. N. Halliday (2009), Fractionation of oxygen and iron isotopes by partial melting processes: Implications for the interpretation of stable isotope signatures in mafic rocks, Earth Planet. Sci. Lett., 283(1-4), 156-166, doi:10.1016/j. epsl.2009.04.011

Woodhead, J. D., M. S. Eggins, and J. Gamble (1993), High field strength and transition element systematics in island arc and back-arc basin basalts: Evidence for multi-phase melt extraction and a depleted mantle wedge, Earth Planet. Sci. Lett., 114, 491-504, doi:10.1016/0012-821X(93) 90078-N.

Zhang, N., and R. N. Pysklywec (2006), Role of mantle flow at the North Fiji Basin: Insights from anomalous topography, Geochem. Geophys. Geosyst., 7, Q12002, doi:10.1029/2006GC001376.

Zhao, D., Y. Xu, D. A. Wiens, L. M. Dorman, J. A. Hildebrand, and S. C. Webb (1997), Depth extent of the Lau back-arc basin spreading centrer and its relation to subduction processes, Science, 278, 254-257, doi:10.1126/science.278.5336.254.

Zhao, X. M., H. F. Zhang, X. K. Zhu, S. H. Tang, and Y. J. Tang (2010), Iron isotope variations in spinel peridotite xenoliths from North China Craton: Implications for mantle metasomatism, Contrib. Mineral. Petrol., 160(1), 1-14, doi:10.1007/s00410-009-0461-y. 